Today, the largest world-class ports consider the opportunities of intercontinental distribution as the most important factor in attracting business. In this regard, the network model will have a direct impact on cargo flows and supply chains, and the proposed estimates include taking into account the economic potential of the region and the interior, forecasting the growth of ports, reviewing transport systems, including infrastructure, analyzing the interconnectedness of modal shifts, and other system integration.

УДК 656.07

DOI: 10.35340/2308-104X.2021.90-1-11

\section{АНАЛІЗ ІНВЕСТИЦІЙНОЇ ПРИВАБЛИВОСТІ МОРСЬКИХ ПОРТІВ УКРАЇНИ}

\author{
КРАВЧЕНКО А. В., \\ кандидат економічних наук, \\ доцент, \\ KOCЯK A. B., \\ магістр, \\ KOCAPEHKO B. B. \\ магістр, Азовський морський \\ інститут національного \\ університету «Одеська морська \\ академія»
}

\section{ANALYSIS OF INVESTMENT ATTRACTIVENESS OF SEAPORTS OF UKRAINE}

\author{
KRAVCHENKO A., \\ $\mathrm{PhD}$ in Economics, Associate \\ Professor, \\ KOSYAK A., \\ Master's student, \\ KOSARENKO V., \\ Master's student, \\ Azov Maritime Institute National \\ University "Odessa Maritime \\ Academy"
}

У статті підкреслено необхідність впровадження методів та прийомів для визначення необхідності інвестування у портову галузь України. Доведено, чому недостатнє інвестування впливає на портову галузь України. Сформовано підгрунтя щодо інвестицій у портову галузь на прикладі портів України.

Ключові слова: інвестиційна привабливість, морські порти.

В статье подчеркнуто необходимость внедрения методов и приемов для определения необходимости инвестирования в портовую отрасль Украины. Доказано, почему недостаточное инвестирование влияет на портовые отрасль Украины. Сформировать основы касательно инвестиций в портовую отрасль на примере портов Украины. порты.

Ключевые слова: инвестиционная привлекательность, морские

The article emphasizes the need to implement methods and techniques to determine the need for investment in the port industry of Ukraine. It is proved why insufficient investment affects the port industry of Ukraine. The basis for investments in the port industry has been formed on the example of Ukrainian ports.

Key words: investment attractiveness, seaports.

Постановка проблеми. Морська галузь України безпосередньо пов'язана з економікою країни в цілому. Продуктивність морської 
галузі залежить безпосередньо від діяльності портів та припортових підприємств.

У портах України безліч проблем. Однією з найбільших проблем $€$ недостатнє інвестування 3 боку держави і приватних інвесторів. Інвестування необхідне для:

- розвитку об'єктів портової інфраструктури; ремонту;

- повного оновлення обладнання або проведення капітального

- поглиблення причалів і морських підхідних каналів;

- будівництва нових причалів і терміналів;

- підвищення рівня захисту екології завдяки доведенню до міжнародних стандартів за допомогою нового, більш досконалого обладнання;

- впровадження більш сучасних технологій.

Метою статті $€$ дослідження основних проблем щодо недостатнього інвестування у розвиток портової галузі України.

Виклад основного матеріалу дослідження. У цілому порти України мають привабливий інвестиційний клімат. Це обумовлено вигідним географічним положенням України, розвиненою транспортною мережею, що пронизує всю територію країни, зручні акваторії, наявністю фахівців різних галузей і здатністю кожного порту досить швидко обробляти різні види вантажів.

Для оцінки ефективності вкладених інвестицій у морську галузь необхідно провести ґрунтовний аналіз внутрішнього та зовнішнього середовища, інакше оцінка виявиться нежиттєздатною. Особливу увагу слід приділити двом групам чинників: сильним і слабким сторонам підприємства.

Ґрунтуючись на результати досліджень вітчизняних учених, а також з огляду на власне дослідження, наведемо основні переваги та можливості, а також недоліки і загрози стратегічного розвитку морських портів України (табл. 1). [2, 6]

Таблиця 1

SWOT-аналіз портової галузі України

\begin{tabular}{|l|l|}
\hline \multicolumn{1}{|c|}{ Переваги } & \multicolumn{1}{|c|}{ Можливості } \\
\hline - Вигідне географічне положення, що & - Організація в морських портах \\
сприяє розвитку морських & кластерів і спеціальних сегментів; \\
транспортних коридорів з країнами & - узгодження національної та \\
СНД по Чорному морю; & експортної політики, з огляду на \\
- експортна потужність потенціал & вимоги морської портової галузі; \\
вантажів чорних металів, вугілля, & - реалізація конкурентної тарифної \\
руди всякої, хлібні, що & політики; \\
характеризується тенденцією до & - введення додаткових пасажиро- та \\
зростання; & вантажопотоків. \\
- вагомі потужності з перевалки & - впровадження приватного капіталу \\
вантажів; & для модернізації, інноватизації \\
- перспектива нарощування & організації портових інфраструктрних \\
вантажопотоків; & об'єктів на підставі договорів концесії, \\
- законодавче забезпечення & а також договорів про спільну \\
залучення інвестицій в галузь; & діяльність; \\
- професіоналізм і висока здатність & -участь в міжнародних організаціях з \\
до навчання фахівців портової галузі; & проблем взаємодії щодо виробництва \\
- одна з кращих у світі систем & додаткових вантажопотоків; \\
підготовки морських фахівців. & -скорочення часу і полегшення \\
& процедури обробки вантажів через \\
& інтегрування інноваційних \\
інформаційних технологій.
\end{tabular}


Продовження табл. 1

\begin{tabular}{|l|l|}
\hline \multicolumn{1}{|c|}{ Недоліки } & \multicolumn{1}{|c|}{ Загрози } \\
\hline - Недосконалість розвитку & - Протиріччя в питаннях зростання \\
механізму введення приватного & перевантажувальних потужностей і, \\
капіталу для забезпечення & як результат, нечесна конкуренція \\
стратегічного розвитку морських & між морськими портами України; \\
портів і захисту інтересів & - зростання числа спеціальних \\
інвесторів; & економічних зон в морських портах \\
зниження рівня прибутковості & Чорноморського басейну; \\
морських портів через зношування & - збільшення потужностей в морських \\
основних засобів; & портах країн Чорноморського \\
- зменшення діапазону транзитних & басейну, розширення сервісних \\
вантажопотоків через низьку якість & послуг по здійсненню \\
виконання вантажно- & вантажооперацій; \\
розвантажувальних робіт, & -скорочення споживчого попиту на \\
недосконалу інфраструктуру & світовому ринку на продукцію \\
морських портів; & вітчизнянго виробництва (сталь, \\
- недосконалість законодавчого & залізорудний концентрат) \\
поля, з питань митного & - низький рівень міжгалузевої \\
оформлення; & координації діяльності з розвитку \\
- повільне оновлення і модернізація & транспортної інфраструктури, \\
основного капіталу морських & викликає неефективно використання \\
портів, а так же їх технічна & ресурсів, а також порушення єдиного \\
невідповідність сервісним вимогам; & транспортного потоку; \\
- зниження рівня завантаженості & - відсутність чіткої спеціалізації \\
морських портів через зменшення & морських портів за видами вантажів, \\
діапазону транзитних & що викликає їх неефективну \\
вантажопотоків. & перевалку; \\
& - нерозвинена транспортна \\
& інфраструктура в морських портах і \\
& на під'їзнх шляхах; \\
- низький рівень технічної безпеки в \\
морських портах. \\
\hline
\end{tabular}

Аналіз сильних і слабких сторін здійснюється за допомогою порівняльних методів. Так, кожна позиція оцінюються за визначеною шкалою оцінки (бальною) та, як правило, ранжирується за важливістю, тобто зважується (для отримання більш достовірних результатів). Конкурентні сили підприємства за окремими позиціями визначаються шляхом порівняння його оцінок за кожною позицією 3 оцінками підприємств-конкурентів.

Потреби інвесторів, які беруть участь в проєктах державноприватного партнерства в морських портах, дещо відрізняються від потреб традиційного інвестування у виробничі об'єкти. Так як метою державної політики залучення приватного капіталу $€$ в основному модернізація, розширення, розвиток інфраструктури галузі, то інвесторів, в першу чергу, цікавить їі стан у об'єкта інвестування, його вантажна база, можливість нарощувати виробничий потенціал, поточна рентабельність, здатність зберігати стійкість в кризових ситуаціях.

Для формування моделі індексу інвестиційної привабливості морського порту було оброблено статистика діяльності державних морських портів України за 2016-2019 рр.

В результаті, були отримані наступні значення основних індикаторів, що включаються в модель індексу інвестиційної привабливості морського порту (табл. 2). 
Розробка індексу інвестиційної привабливості - складна і вимагає теоретичного обґрунтування завдання, так як при його формуванні необхідно враховувати ступінь взаємодії, включаються в модель факторів, різниця їх розмірних величин, рівень важливості для кінцевого результату. При цьому, попри те, що індекс $є$ відносною величиною i не передбачає простого підсумовування середніх значень різнорідних чинників, їх підбір в модель повинен бути обґрунтованим і відповідати завданням i дозволяти проводити порівняння і узагальнення. [4]

Таблиця 2

Значення показників, обраних в модель індексу інвестиційної привабливості морського порту

\begin{tabular}{|c|c|c|c|c|c|c|c|c|c|}
\hline Назва порту & 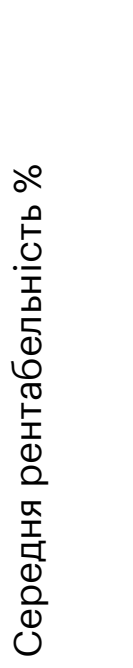 & 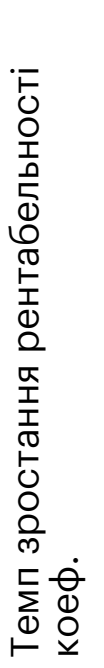 & 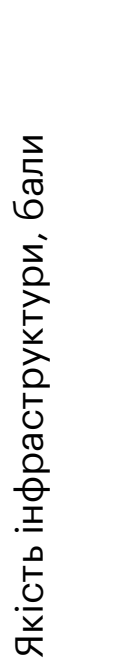 & 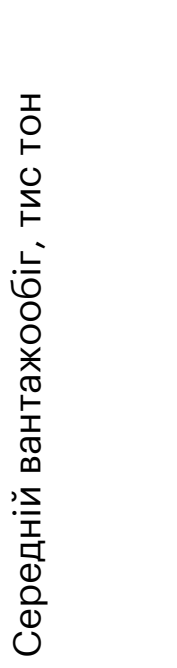 & 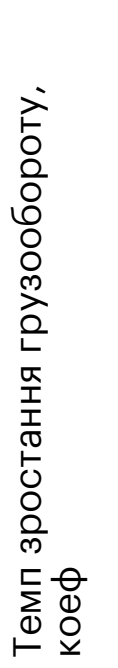 & 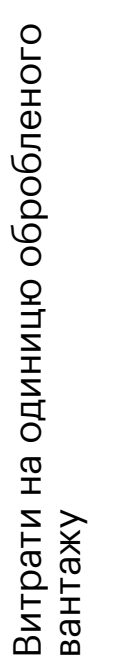 & 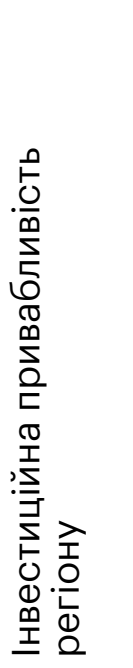 & 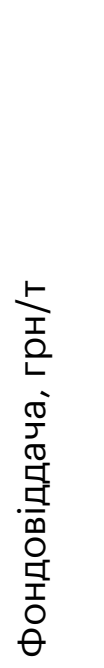 & 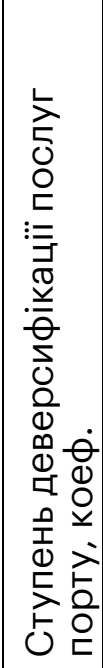 \\
\hline Херсонський & 6,19 & 1,28 & 10,23 & 3013,4 & 1,036 & 61,39 & 1,3228 & 0,11 & 12 \\
\hline Одеський & 49,08 & 2,55 & 2,25 & 25053,4 & 0,96 & 41,79 & 1,3775 & 0,29 & 16 \\
\hline Южний & 31,99 & 1,68 & 4,5 & 22649,6 & 1,00 & 59,17 & 1,3775 & 0,29 & 7 \\
\hline Маріупольський & 38,98 & 1,88 & 4,25 & 14567,2 & 0,94 & 76,34 & 1,4708 & 0,52 & 13 \\
\hline Чорноморськ & 10,89 & 1,01 & 6,25 & 14022,0 & 1,07 & 83,83 & 1,3775 & 0,25 & 14 \\
\hline Бердянський & 4,53 & 0,77 & 9,75 & 2372,0 & 0,96 & 94,89 & 1,2703 & - & 8 \\
\hline Ізмаїльський & 0,96 & 0,00 & 8 & 3929,2 & 0,59 & 77,71 & 1,3775 & 0,16 & 9 \\
\hline
\end{tabular}

Важливим етапом формування будь-якого індексу $є$ ранжування вводяться в нього показників за ступенем важливості і розрахунок відповідних коефіцієнтів, що дозволяє виділити найбільш значущі чинники і надати їм більшої ваги при розрахунку кінцевого значення результуючого показника.

Визначити коефіцієнти важливості що вводяться в індекс інвестиційної привабливості характеристик діяльності морського порту можна за допомогою експертних оцінок бальним методом. В якості експертів залучаються фахівці портової галузі.

Для визначення важливості індикаторів їм було запропоновано присвоїти зазначеним восьми показниками бали від 1 до 8. Потім отримані оцінки були перетворені в коефіцієнти вагомості [3].

В цілому, експерти зійшлися на думці, що найбільш важливими є показники рентабельності, вантажообігу, якості інфраструктури та фондовіддача. 
Таблиця 3

Оцінка важливості індикаторів індексу інвестиційної привабливості морських портів

\begin{tabular}{|c|c|c|c|c|c|c|c|}
\hline \multirow[b]{2}{*}{ Показник } & \multicolumn{6}{|c|}{ Експертні оцінки, в балах } & \multirow[b]{2}{*}{$\begin{array}{c}\text { Коеф. } \\
\text { вагомості }\end{array}$} \\
\hline & $\begin{array}{c}1 \\
\text { експерт }\end{array}$ & $\begin{array}{c}2 \\
\text { експерт }\end{array}$ & $\begin{array}{c}3 \\
\text { експерт }\end{array}$ & $\begin{array}{c}4 \\
\text { експерт }\end{array}$ & $\begin{array}{c}5 \\
\text { експерт }\end{array}$ & $\begin{array}{c}6 \\
\text { експерт }\end{array}$ & \\
\hline $\begin{array}{l}\text { Середня } \\
\text { рентабельність }\end{array}$ & 6 & 7 & 6 & 8 & 8 & 6 & 0,1898 \\
\hline $\begin{array}{l}\text { Темп зросту } \\
\text { рентабельності }\end{array}$ & 1 & 2 & 1 & 3 & 2 & 2 & 0,0509 \\
\hline $\begin{array}{l}\text { Якість } \\
\text { інфраструктури }\end{array}$ & 8 & 6 & 8 & 5 & 6 & 7 & 0,1852 \\
\hline $\begin{array}{l}\text { Середній } \\
\text { вантажообіг }\end{array}$ & 7 & 8 & 5 & 6 & 7 & 8 & 0,1898 \\
\hline $\begin{array}{l}\text { Темп зросту } \\
\text { вантажообігу }\end{array}$ & 5 & 4 & 3 & 4 & 1 & 1 & 0,0833 \\
\hline $\begin{array}{l}\text { Витрати на од. } \\
\text { обробленого } \\
\text { вантажу }\end{array}$ & 2 & 1 & 2 & 2 & 5 & 5 & 0,0787 \\
\hline Фондовіддача & 4 & 5 & 4 & 7 & 4 & 4 & 0,1296 \\
\hline $\begin{array}{l}\text { Ступінь } \\
\text { диверсифікації } \\
\text { послуг порту }\end{array}$ & 3 & 3 & 1 & 1 & 3 & 3 & 0,0926 \\
\hline
\end{tabular}

Регіональні умови, зовнішнє оточення порту буде відігравати суттєву роль в стратегії його розвитку, так як інвестиційна привабливість регіону характеризує такі важливі параметри як:

- демографічна ситуація;

- рівень промислового виробництва;

- природні ресурси;

- стан інфраструктури;

- розвиток бізнес сегмента.

Тому доцільно було 6 скорегувати отримані індекси інвестиційної привабливості морських портів на рівень привабливості самого регіону.

Результати розрахунку індексу інвестиційної привабливості за державними морським портам України представлені на рис. 1.

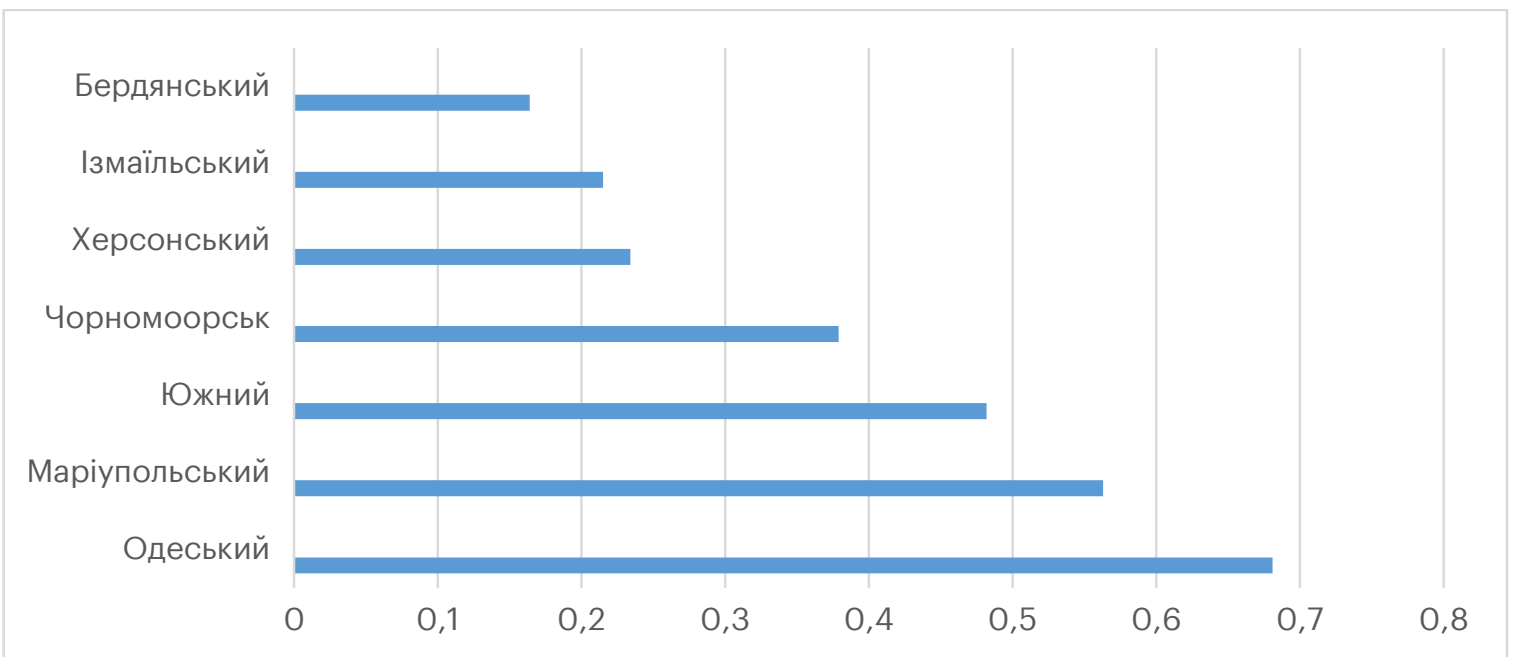

Рис. 1. Бальний рейтинг інвестиційної привабливості портів 
Отриманий рейтинг інвестиційної привабливості дозволяє зробити наступні висновки про стан державних морських портів України на 2019 р. Беззаперечним лідером галузі практично по всім параметрам, які вводяться в модель, $€$ Одеський морський торговельний порт.

Портова галузь дуже капіталомістка. Так як держава не може забезпечити необхідний рівень фінансування, порти потребують інвестування. Нині на шляху інвестора виникає безліч проблем, проте, не дивлячись на це, іноземні інвестори все ж поки проявляють інтерес до українських портів. І основним завданням з боку держави докладати всіх необхідних зусиль для залучення нових інвесторів, створення позитивного інвестиційного клімату та необхідного правового поля. Адже тільки за рахунок інвестицій можна проводити ремонт, технічне переоснащення, будівництво та підвищення загального рівня конкурентоспроможності портів на світовому ринку [1].

Висновки та перспективи подальших досліджень. Таким чином, для оцінки ефективності вкладених інвестицій у морську галузь було проведено ґрунтовний аналіз внутрішнього та зовнішнього середовища, а також виявлено кореляційний зв'язок з урахуванням найбільш важливих показників рентабельності, вантажообігу, якості інфраструктури та фондовіддачі. 3 метою підвищення вантажообігу, розширення свого контейнерного потенціалу, а також збільшення кількості суднозаходів як порти України, так і провідні світові порти активно продовжують реалізацію інвестиційних проєктів. Це дозволяє портам зберегти за собою лідерські позиції, порт бути конкурентоспроможним на світовому ринку.

\section{Література:}

1. Толкаченко О.Ю. Класифікація підходів до визначення інвестиційної привабливості підприємства. Транспортна справа Росії. 2008. №4. URL:http://www.morvesti.ru/archivetdr/element.php?IBLOC K_ID=66\&SECTION_ID=1353\&ELEMENT_ID=3058).

2. Машкін В.А. Управління інвестиційною привабливістю реального сектора економіки регіону. URL: http://www.b_news.narod.ru/economy/mmanagement.htm.

3. Методика інтегральної оцінки інвестіційної пріваблівості підприємств та організацій: Затверджено наказом Агентства по вопросам Запобігання банкрутству підприємств та організацій 23.02.98. № 22. Державний інформ. бюл. про приватизацію. 1998. № 7. C. $18-28$.

4. Носова О.В. Інвестиційна привабливість підприємства. Стратегічні Пріоритети. 2007. №1 (2) С. 120-126.

5. Буднікова Ю. В. Інвестиційна привабливість підприємства та фактори впліву на неї. Інноваційна економіка. Всеукраїнський наукововиробничій журнал. 2011. №4. С. 194-197.

6. Рейтинг інвестиційної привабливості регіонів. Державне агентство з інвестицій та управління Національними проектами. URL: http://www.ukrproject.gov.ua/sites/default/files/upload/reyting_investi ciynoyi_privablivosti_regioniv_.pdf.

7. Ромашкіна Г. Ф., Татарова Г. Г. Коефіцієнт конкордації в аналізі соціологічних даних. Соціологія 4M. 2005. №20. С. 131-157. URL:http://ecsocman.hse.ru/data/2012/04/10/1271933327/Romashkina 20Tatarova.pdf. 
8. Скібітська Л. У., Скібіцькій О. М. Менеджмент: підручник. Москва: ЦУЛ опубл., 2007. 416 с.

Referenses:

1. Tolkachenko O. Ju. Klasyfikacija pidkhodiv do vyznachennja investycijnoji pryvablyvosti pidpryjemstva. Transportne sprava Rosiji. 2008. \#4. URL:http://www.morvesti.ru/archivetdr/element.php?IBLOCK _ID=66\&SECTION_ID=1353\&ELEMENT_ID=3058).

2. Mashkin V. A. Upravlinnja investycijnoju pryvablyvistju realjnogho sektora ekonomiky reghionu. URL: http://www.b_news.narod.ru/economy/mmanagement.htm.

3. Metódyka integhraljnoji ocinky investicijnoji privablivosti pidpryjemstv ta orghanizacij: Zatverdzheno nakazom Aghentstva po voprosam Zapobighannja bankrutstvu pidpryjemstv ta orghanizacij 23.02.98. \# 22. Derzhavnyj inform. bjul. pro pryvatyzaciju. 1998. \# 7. C. $18-28$.

4. Nosova O. V. Investycijna pryvablyvistj pidpryjemstva. Strateghichni Priorytety. 2007. \#1 (2) S. 120-126.

5. Budnikova Ju. V. Investycijna pryvablyvistj pidpryjemstva ta faktory vplivu na neji. Innovacijna ekonomika. Vseukrajinsjkyj naukovovyrobnychij zhurnal. 2011. \#4. S. 194-197.

6. Rejtyngh investycijnoji pryvablyvosti reghioniv. Derzhavne aghentstvo z investycij ta upravlinnja Nacionaljnymy proektamy. URL: http://www.ukrproject.gov.ua/sites/default/files/upload/reyting_investi ciynoyi_privablivosti_regioniv_.pdf.

7. Romashkina Gh. F., Tatarova Gh. Gh. Koeficijent konkordaciji v analizi sociologhichnykh danykh. Sociologhija 4M. 2005. \#20. S. 131-157. URL:http://ecsocman.hse.ru/data/2012/04/10/1271933327/R omashkina,20Tatarova.pdf.

8. Skibitsjka L. U., Skibicjkij O. M. Menedzhment: pidruchnyk. Moskva: CUL opubl., 2007. 416 s.

Ukraine's maritime industry is directly related to the country's economy as a whole. The productivity of the maritime industry depends directly on the activities of ports and port enterprises. There are many problems in the ports of Ukraine. One of the biggest problems is insufficient investment by the state and private investors. Investment is required for: development of port infrastructure facilities; complete equipment upgrade or overhaul; deepening of berths and sea approach channels; construction of new berths and terminals; increasing the level of environmental protection by bringing it to international standards with the help of new, more advanced equipment; introduction of more modern technologies. In the article, the authors emphasized the need to introduce methods and techniques to determine the need to invest in the port industry of Ukraine. The basis for investment in the port industry has been formed on the example of the ports of Ukraine. The authors note that there are many problems in the ports of Ukraine. One of the biggest problems is underinvestment on the part of the state and private investors. This factor influences the efficient operation of the seaports of Ukraine, as well as their further development. A literature review conducted by the authors showed that in order to assess the effectiveness of investment 
in the maritime industry, it is necessary to conduct a deep analysis of the internal and external environment, which will highlight the strengths and weaknesses of the strategic development of the seaports of Ukraine. The authors have proven that the ports of Ukraine have an attractive investment climate. This is due to the favorable geographical position of Ukraine, the location of transport networks that permeate the entire territory of the country, convenient water areas, the presence of specialists from different industries and the ability of each port to handle various types of cargo quickly enough. So, with the aim of increasing cargo turnover, expanding its container potential, as well as increasing the number of ship calls both at the ports of Ukraine and the world's leading ports, they are actively continuing to implement investment projects.

УДК 338.434(477.44)

DOI: $10.35340 / 2308-104 X .2021 .90-1-12$

\section{ФІНАНСОВЕ ЗАБЕЗПЕЧЕННЯ ДІЯЛЬНОСТІ ПІДПРИЄМСТВ АГРАРНОГО СЕКТОРА}

\author{
КРУЧИНЕНКО В. А.,
}

здобувач третього рівня вищої освіти спеціальності 051

«Економіка», Херсонський державний аграрно-економічний університет

\section{FINANCIAL SUPPORT OF ACTIVITY OF AGRICULTURAL SECTOR ENTERPRISES}

\author{
KRUCHYNENKO V., \\ Post-graduate Student in the \\ specialty 051 "Economics", \\ Kherson State Agrarian and \\ Economic University
}

\begin{abstract}
В даній науковій роботі визначено зміст категорії «фінансове забезпечення». За допомогою кореляційнорегресійного аналізу встановлено значущість джерел фінансового забезпечення розвитку аграрного сектору. Сформовані моделі множинної регресії, які описують залежність параметрів такого розвитку $i$ обсягів ресурсів за різними джерелами фінансового забезпечення.
\end{abstract}

Ключові слова: фінансове забезпечення, підприємства, аграрний сектор, кореляційно-регресійний аналіз, ресурси.

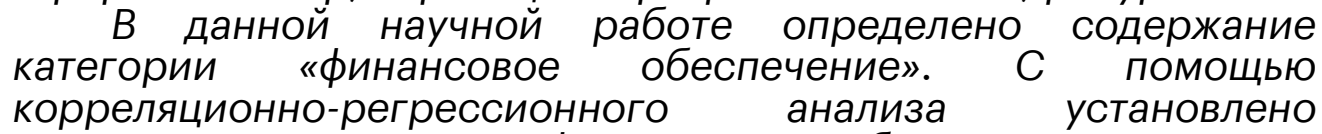
значимость источников финансового обеспечения развития аграрного сектора. Сформированны модели множественной регрессии, описывающие зависимость параметров такого развития и объемов ресурсов по источникам финансового обеспечения.

Ключевые слова: финансовое обеспечение, предприятия, аграрный сектор, корреляционно-регрессионный анализ, ресурсы.

In this scientific work the content of the category "financial support" is defined. With the help of correlation-regression 